\title{
IAMJ
}

INTERNATIONAL

AYURVEDIC

MEDICAL JOURNAL

\section{REVIEW OF SHOOLA WITH SPECIAL REFERENCE TO MADHAV NIDAN}

\section{$\underline{\text { Kulkarni Archana } \mathbf{A}^{1}}$., Joshi Seema D. ${ }^{2}$}

${ }^{1}$ Professor, Dept. of Rog Nidan and Vkruti Vignyan, BSDT's Ayurved College, Wagholi, Pune, Maharashtra, India

${ }^{2}$ Assistant Professor, Dept. of Rachana Sharir, BSDT's Ayurved College, Wagholi, Pune, Maharashtra, India

Corresponding Author: archana.arukulkarni@gmail.com

\section{https://doi.org/10.46607/iamj05p5052021}

(Published online: July 2021)

Open Access

(C) International Ayurvedic Medical Journal, India 2021

Article Received: 08/06/2021 - Peer Reviewed: 02/07/2021 - Accepted for Publication: 03/07/2021

Check for updates

\begin{abstract}
Ayurveda, the science of life not only emphasises the curative aspect of disease but also gives knowledge about the prevention of disease. The Ayurvedic diagnostic approach comprises Rogi Pariksha and Roga Pariksha separately. A proper diagnosis forms the basis for appropriate treatment whereas ignorance of it leads to haphazard. So, diagnosis of the disease comes first. Shoola is the commonest symptom mentioned in Ayurvedic text produced due to the prominence of Vata either due to Margavarodha or due to Swatantra Vata Prakopa. Madhavkar is the first who mentioned a special chapter describing Shoola is a Swatantra Vyadhi. He also elaborates on different types of Doshaj Shoola along with Amaj, Parinama Shoola and Annadrava Shoola. An attempt is made to review the Shoola from various ayurvedic texts with special reference to Madhav Nidan. Before initiating any treatment, it is necessary to differentiate the Shoola as a disease or as a symptom. Shoola explained by Madhavkara specifically explains Udarshoola. With the help better understanding of pathogenesis and proper diagnosis of the disease, its treatment can be planed.
\end{abstract}

Keywords: Annadravashoola, Parinamashoola, Pain, Shoola, 


\section{INTRODUCTION}

Ayurveda, the science of life not only emphasises the curative aspect of disease but also gives knowledge about the prevention of disease through Sadvrutta ${ }^{[1]}$. Human beings are more prone to diseases even after following the Dincharya, Rutucharya etc. According to Ayurveda, the disease is a state of the body and mind that gives pain and discomfort to a human being. For treating the disease Hetu (cause), Linga (symptoms) and Aushadha (medicine) are the Trisutra mentioned in Ayurveda ${ }^{[2]}$. Out of these three Sutra, two are meant for diagnosis of disease and the third one is meant for treatment purposes. Also, it is stated that a physician should first diagnose the disease and then select the proper medicine for the treatment of the disease ${ }^{[3]}$. The Ayurvedic diagnostic approach comprises Rogi Pariksha and Roga Pariksha separately. Roga Pariksha includes Nidana panchaka namely Nidana, Purvaroopa, Roopa, Upashaya and Samprapti ${ }^{[4]}$. Roga Pariksha is not only important rather it is the foremost part for diagnosis of diseases. Knowledge of Nidana Panchaka is not only useful for the diagnosis of disease but also gives information about prognosis, treatment, and differential diagnosis of the disease. A proper diagnosis forms the basis for appropriate treatment whereas ignorance of it or improper diagnosis leads to haphazard. So, the diagnosis of the disease comes first. Like Jwar, shoola is the most common Purvaroopa (prodromal symptoms) or Roopa (signs and symptoms) or Upadrava mentioned in several diseases. But there is no special chapter for shoola in the Brihatrayee of Ayurveda. Discrete description of it is observed in several chapters during the description of the disease, either as Purvaroopa (prodromal symptoms), Roopa (signs and symptoms) or Upadrava (complications). From the very beginning in the Bheshaja Chatushka of Charaka, there are different medicinal preparations for the management of pain in different parts of the body. Likewise, in the Charaka Sutra Sthana fourth Chapter, there are two Mahakashaya directly mentioned for the management of pain i.e. Shoola Prashamana and the Vedanasthapa$n a$, also there is another one that directly relates to pain management as Angamarda Prashamana [5]. Sushruta has explained Shoola as abdominal pain in his Uttar Tantra ${ }^{[6]}$. He has also explained Shoola as the main Upadrava (complication) of Gulma in the same chapter. In Madhava Nidana, for the first time a special chapter is mentioned for Shoola after Amavata Nidan ${ }^{[7]}$. It may be due to the presence of a characteristic type of pain in Amavata. In all types of Shoola, Vata is the predominant causative factor. Considering the importance of Shoola in the diagnosis of disease an attempt is made to review Shoola from classical Ayurvedic text with special reference to Madhav Nidan. Madhavkar (16th century A.D.) is the first who explains Shoola as Swatantra Rog. He also elaborates its different Doshaj types along with $A n$ nadrava Shool and Parinam Shoola. From this review and critical analysis, it can be concluded that Shoola is the most common Purvaroopa, Roopa or Upadrava indicating various disease pathology. Before initiating any treatment, it is necessary to differentiate the Shoola according to its cause, site, Doshaprabalya or as per Upashya-Anupashaya. Thus, the proper diagnosis of disease leads to proper planning of treatment.

AIM AND OBJECTIVE: To review and analyse the literature regarding Shoola from the ayurvedic text.

\section{MATERIALS AND METHODS: -}

MATERIALS: - Brihatrayee and Madhav Nidan along with their commentaries and few elementary textbooks, research journals and articles.

METHOD: - Collection of information from the Ayurvedic text and research articles. Analysis of data was carried out.

\section{REVIEW OF LITERATURE}

A. Definition: According to Vruddha Sushruta, pain in the abdomen resembling "Shanku Sphotanavat" i.e., pricking pain due to iron hook piercing in the abdomen is called Shoola ${ }^{[8]}$.

B. The etymology of Shoola: Shoola is a Pullingi Shabda. It conveys the meaning of Rujayam, Vyathayam ${ }^{[9]}$. Ayurvediya Shabdakosha indicates the different contexts wherein the word is used in the classics as a Lakshana, Ruja or Roga ${ }^{[10]}$. As 
per Moinier Williams, Shoola is any sharp or acute pain especially that of colic /gout pain, sorrow, grief ${ }^{[11]}$. Sushruta mentions Shoola is a condition where the patient experiences the sharp intensity of pain as if pierced with Shanku i.e. Keelaka or Kantaka.

\section{Mythological Review:}

According to Madhav nidana, once when lord Shiva was furious due to the disturbance produced by Anang (Kamadeva) during his meditation, he threw his Trishula towards Kamadeva. To escape from the attack of Trishula, Kamdeva entered lord Vishu's body. To protect him, Vishudev heaved, and his sigh made the Trishula fall on the earth and there is created Shoola. As it is originated from Trishula it is called Shoola ${ }^{[12]}$.

This condition has not been mentioned in any of Brihatrayee. Later Acharyas of Laghutrayee have explained Shoola as a separate entity.

D. Synonyms of Shoola: There are different synonyms related to Pain in Ayurveda i.e.-Shoola, Rooja, Rook, Vedana, Arati etc.

\section{E. Samhita Review}

\section{Charak Samhita:-}

In Sutra Sthana "Shoola Prashamana Gana" is mentioned [5]. Viman Sthana mentions Amatra Bhojana leading to Shoola ${ }^{[13]}$. Gulma is designated as a Vedana Pradhana Vyadhi ${ }^{[14]}$. Shoola is explained as a Lakshana in Vataj Grahani ${ }^{[15]}$. Shoola is also a Lakshana of Prakupita Vata in the Kukshi. Shoola, Gul$m a$ are seen in Kosthashrit Vata ${ }^{[16]}$. Amashaygata Vata and Pakvashayagata Vata also have Shoola as their symptom. Among Avruta Vata Pittavruta Vata, Kaphavruta Vata ${ }^{[17]}$ and Samanavruta Apana have Shoola as a Lakshana.

\section{Sushrut Samhita}

Sushruta has explained Shoola as abdominal pain in his Uttar Tantra ${ }^{[7]}$. He has also explained Shoola as the main Upadrava (complication) of Gulma in the same chapter. Parshva-Shoola, Kukshi Shoola, Hrit Shoola, Basti and Mutra Shoola and Annaj Shoola are also mentioned by Sushruta.

\section{Ashtang Hruday}

Just like Charak no special chapter on Shoola is mentioned in Ashtang hruday.

\section{Madhav Nidan}

Madhavakara is the first author who mentioned an independent disease status to Shoola ${ }^{[8]}$.

\section{F. Nidan Panchak}

\section{Hetu $^{[18]}$ :}

According to Ayurveda, all types of Ruja are considered under Vata aggravation. Pain can only occur if the Vata is vitiated. So, the causes responsible for Vatavyadhi can be considered for vitiation of Vata Dosha. These causes can be divided into two groups:

1. Swatantra Vata Dosha Prakopak Hetu And

2. Paratantra Vata Dosha Prakopak Hetu.

Vegasandharana (suppression of natural urges) and Marmabhighata (trauma to vital organs) etc. are examples of Swantra Vata Dosha Prakopak Hetu. Whereas Divaswapna (day sleep) does not directly lead to vitiation of Vata. However, it leads to the formation of Ama and causes Vata vitiation indirectly by obstructing Vata. Due to this, Vata gets vitiated and brings Rukshata, Laghava, Kharatva which causes symptoms of pain, leading to various generalized or localized disorders.

Samprapti ${ }^{[18]}$ : Deranged and aggravated Vata Dosha get accumulate at the site where Khavaigunya is present and produces Shoola (a spasmodic pain) in the Koshtha (abdominal cavity). A patient complains of Shanku Spotanvat (piercing pain), hence named as Shoola.

Purvaroopa ${ }^{[18]}$ : - as it is a Vatavyadhi, indistinct manifestation of the diseases can be considered as prodrome symptoms.

Following are the Vyadhi Ghatakas considered in the pathogenesis of Shoola.

Dosha:- Tri-Dosha, Predominantly Vata, Dushya:Rasa Dhatu, Strotas:- Annavaha, Agni:- Jatharagimandya, Aam:- Jatharagnimandya Janit., Strotodushti :- Atipravruti Or Sangapradhan

Type of Pain /Shoola according to Ayurveda: -

1) Sushruta:- Vataja, Pittaja, Kaphaja, Sannipataja

Parshva Shoola, Kukshi Shoola, Hrit Shoola, Basti 
Shoola, Mootra Shoola, Vit Shoola, Avipaka/Anna Dosaja Shoola ${ }^{[19]}$.

2)Madhavakara:- Vataja, Pittaja, Kaphaja, Vatapittaja, Vata-kaphaja, Pitta-kaphaja, Sannipataja, Amaj, Parinama Shoola and Annadrava Shoola. Parinama Shoola and Annadrava Shoola closely resembled to peptic ulcers and have strong relationships with food intake. In all types, Vata is the predominant causative factor.

Parinama Shoola ${ }^{20}$ :-

Parinama shoola term is a self-explanatory i.e. Shoola or abdominal colic that is experienced during the digestion of food i.e. 3-4 hours after intake of food when food had reached the intestines. Parinama Shoola is an Avaranjanya Tridoshaja Vyadhi.

Synonyms:- Annadrava Shoola, Paktidoshaj Shoola, Annavidahaja Shoola.

Samprapti:- Vata being vitiated by Swanidan which in turn does the Avarana of Kapha and Pitta leading to Parinama Shoola.

Lakshana:- Abdominal pain precipitates and aggravates during digestion of food and get relieved after digestion of food or by Vaman or after intake of food. The common sites of pain include Kukshi (Epigastric region), Jathara-Parshva (Right and Left Hypochondria), Nabhi (Umbilical region), Basti (Hypogastric region), Stanantra (Retrosternal) etc. As per Madhav Nidaan, Parinaam Shoola has also been described as Durvigneya Mahagada.

Madhavakara has described seven types of Parinama shoola viz. Vataj, Pittaj, Kaphaj, three samsargaja and one Sannipataj.

Annadrava Shoola ${ }^{21}$ -

Annadrava Shoola is described as a type of shoola by Acharya Madhav having the characteristic features of pain before and during digestion of food and that relieves after vomiting. Annadrava Shoola is explained as due to Vata Prakopa, the aggravated Vata Dosha encircles nearby located Pitta and Kapha Dosha in the Koshtha and becomes powerful enough to produce colic pain during the digestion of ingested food and Kapha breaks down from its location and interact with Pitta and combines with Vata to cause colic pain during the transformation process of the consumed food and this typical Shoola is known as Anndrava Shool.

Lakshana:- Burning sensation in the epigastrium, Pain before a meal, during digestion or any time and is continuous. It relieves after vomiting.

In modern science, these can be correlated with peptic ulcers.

Table 1: Types of Shoola and their symptoms

\begin{tabular}{|c|c|c|c|c|c|}
\hline $\begin{array}{l}\text { Type of } \\
\text { Shoola }\end{array}$ & Site & Nature of Shoola & Associated symptoms & $\begin{array}{l}\text { Aggravating Fac- } \\
\text { tors }\end{array}$ & Relived by \\
\hline Vataja & $\begin{array}{l}\text { Pain in heart, } \\
\text { flanks, back, } \\
\text { waist and uri- } \\
\text { nary bladder }\end{array}$ & $\begin{array}{l}\text { Pain increases or } \\
\text { decreases on its } \\
\text { own accord fre- } \\
\text { quently, Pricking } \\
\text { or tearing type }\end{array}$ & $\begin{array}{l}\text { Obstruction to stool } \\
\text { and flatus }\end{array}$ & $\begin{array}{l}\text { During cold weather, } \\
\text { in the evening, dur- } \\
\text { ing or after digestion } \\
\text { of food, cloudy and } \\
\text { cold weather }\end{array}$ & $\begin{array}{l}\text { Hot fomentation, } \\
\text { oil massage, } \\
\text { Fatty and warm } \\
\text { foods and drinks. }\end{array}$ \\
\hline Pittaja & Near umbilicus & Burning sensation & $\begin{array}{l}\text { Thirst, confusion, per- } \\
\text { spiration, fainting, gid- } \\
\text { diness }\end{array}$ & $\begin{array}{l}\text { During mid-day, } \\
\text { midnight, digestion, } \\
\text { in the rainy season }\end{array}$ & $\begin{array}{l}\text { Cold substances } \\
\text { like cold drinks } \\
\text { and cold exposure, } \\
\text { sweet foods and } \\
\text { sweet drinks }\end{array}$ \\
\hline Kaphaja & $\begin{array}{l}\text { Pain near the } \\
\text { stomach with } \\
\text { stiffness loss of } \\
\text { movements }\end{array}$ & Dull aching pain & $\begin{array}{l}\text { Heaviness in head, } \\
\text { nausea, cough, debility, } \\
\text { Anorexia, Salivation }\end{array}$ & $\begin{array}{l}\text { Severe in morning at } \\
\text { sunrise, in Sishira } \\
\text { and Vasanta, and } \\
\text { after taking food }\end{array}$ & -- \\
\hline Vatapittaja & & Severe pain & Burning sensation and & -- & -- \\
\hline
\end{tabular}




\begin{tabular}{|c|c|c|c|c|c|}
\hline & & & fever & & \\
\hline $\begin{array}{l}\text { Kapha- } \\
\text { pittaja }\end{array}$ & $\begin{array}{l}\text { Abdomen, heart } \\
\text { and centre of } \\
\text { the umbilicus }\end{array}$ & -- & -- & -- & -- \\
\hline $\begin{array}{l}\text { Kapha- } \\
\text { vataja }\end{array}$ & $\begin{array}{l}\text { Heart, sides of } \\
\text { chest and back }\end{array}$ & -- & -- & -- & -- \\
\hline Sannipataja & -- & Severe pain & -- & $\begin{array}{l}\text { Severe form during } \\
\text { all the times }\end{array}$ & -- \\
\hline $\begin{array}{l}\text { Amaj Shoo- } \\
\text { la }\end{array}$ & -- & $\begin{array}{l}\text { Associated with } \\
\text { Gurgling sound in } \\
\text { the intestine }\end{array}$ & $\begin{array}{l}\text { Nausea, vomiting, } \\
\text { heaviness, rigidity, } \\
\text { distension of abdomen } \\
\text { salivation also other } \\
\text { symptoms like Kaphaj } \\
\text { Shoola }\end{array}$ & -- & -- \\
\hline $\begin{array}{l}\text { Parinama } \\
\text { Shoola }\end{array}$ & $\begin{array}{l}\text { Kukshi, Jatha- } \\
\text { ra-Parshva, } \\
\text { Nabhi Basti, } \\
\text { Stanantra }\end{array}$ & $\begin{array}{l}\text { During digestion } \\
\text { of food }\end{array}$ & $\begin{array}{l}\text { As per the predomi- } \\
\text { nance of dosha }\end{array}$ & Digestion of food & $\begin{array}{l}\text { After digestion of } \\
\text { food or by Vaman } \\
\text { or after intake of } \\
\text { food }\end{array}$ \\
\hline $\begin{array}{l}\text { Annadrava } \\
\text { shoola }\end{array}$ & $\begin{array}{l}\text { In the epigas- } \\
\text { trium }\end{array}$ & $\begin{array}{l}\text { Continuous and } \\
\text { severe pain }\end{array}$ & -- & $\begin{array}{l}\text { Pain before a meal, } \\
\text { during digestion or } \\
\text { any time }\end{array}$ & $\begin{array}{l}\text { It relieves after } \\
\text { vomiting }\end{array}$ \\
\hline
\end{tabular}

\section{G. Modern Review of abdominal Pain}

Pain in the abdomen is the single most important symptom of an acute abdominal pathologic process. It is the symptom that brings the patient to his physician and the symptom that deserves the utmost care in evaluation.

Abdominal pain occurs when mechanical or chemical stimuli trigger the pain receptors in the abdomen. Stretch is the primary mechanical stimulus. Other mechanical stimuli, such as expansion, contraction, compression, pulling, and twisting of the viscera, also induce pain.

\section{Types of Abdominal Pain}

\section{Visceral Pain}

Visceral pain is considered a vague and dull pain because the majority of organs and the visceral peritoneum do not carry an abundance of nerve fibres for pain. Foregut structures (stomach, duodenum, liver, and pancreas) cause upper abdominal pain. Midgut structures (small bowel, proximal colon, and appendix) cause periumbilical pain. Hindgut structures (distal colon and genitourinary tract) cause lower abdominal pain.
The patient may experience mild pain that is poorly localized, with the exact location difficult to pinpoint.

\section{Parietal Pain}

Parietal pain, or somatic pain, occurs when there is an irritation of the parietal peritoneum that lines the abdominal cavity. Somatic pain comes from the parietal peritoneum, which is innervated by somatic nerves, which respond to irritation from infectious, chemical, or other inflammatory processes. Somatic pain is sharp, constant, severe, and is easily localized.

\section{Referred Pain}

Referred pain is perceived distant from its source. It is poorly localized but normally constant. It occurs when organs share a common nerve pathway.

For example, the pain due to phrenic nerve irritation is referred to as the ipsilateral shoulder. The phrenic nerve has the same nerve value (C3-C5) as the cutaneous nerves supplying the shoulder. Therefore, when afferent nerves transmit the information to the brain, the brain misinterprets and localizes the pain to the shoulder when, in fact, the problem lies within the phrenic nerve and not the shoulder. 


\section{Common examples of referred pain in the human} body are as follows:

- Referred pain of a ureteric stone into the groin

- Acute myocardial infarction pain referred to the left arm and jaw

The differential diagnosis of abdominal pain varies widely, ranging from benign to life-threatening conditions, so a stepwise approach is required to identify the exact cause and its severity.

\section{DISCUSSION}

Shoola is a common symptom in most diseases. Shoola is termed as Ruk, Ruja, Vedana etc in various diseases as Purvaroopa, Roopa or Upadrava. No special chapter described Shoola as Swatantra Vyadhi in Brihatrayee, but Sushruta is the first who described Shoola as Upadrava of Gulma or may be present without the complication of Gulma. Sushruta explains Doshaj Shoola and also the Shoola according to the site of affection. Madhavkar is the first who mentioned a special chapter describing Shoola is a Swatantra Vyadhi. He also elaborated on different types of Doshaj Shoola along with Amaj, Parinama Shoola and Annadrava Shoola. Shoola is the predominant sign produced due to vitiation of Vata Dosha. Vitiation of Vata may be due to Swantara Vata Prakopaka Hetu or due to Maragavarodha. Various causes of Margavarodha or Avaran are Mala, Sama Dosha or Shalya. In Madhav Nidan Shoola Vyadhi specifically indicate Udarashoola. In Madhav Nidan, the disease Shoola is mentioned after Amavata Nidan in which there is a predominant or characteristic type of Shoola (Vruchikdansha Vata vedena). Considering the importance of Shoola a separate chapter has been explained on this symptom. In the Samprapti of Shoola Vata vitiation is of utmost importance. Vata Dosha gets vitiated either due to Swatantra Hetu like Ati Ruksha Annasevan, Vegavidharan or Paratantra Hetu includes Samadosha, Mala Sanga or Shalya etc. vitiated Vata gets lodged at the site where there is Khavaigunya. Some characteristics attributed to pain are site, character, associated symptoms, timing (duration, course and pattern) exacerbating and relieving factors, severity and onset. First is the site i.e Ashraya of Shoola. If it is in Kati Pradesha then Vata Dosha is predominant, in umbilical region Pitta Pradhan and if near the stomach region then Kapha Pradhanta should be considered. The site also gives information about the Vikalpa Samprapti of Shoola. Shirashoola indicates the involvement of Prana Vayu. If there is a pain in the flanks, it will be Udana Vata Vaigunya. Abdominal colic, there is an involvement of Samana Vata. The second factor is character. i.e different types of Shoola like Ruja, Toda, Bheda etc are mentioned in classics related to Vata Pradhanya, burning or Chosh or Osh represents Pitta Pradhanya, whereas Manda or dull pain and Angamarda represents Kapha Pradhanya. Gurgling sound in the intestine is associated with Amaj Shoola. The third factor is associated symptoms i.e if the Shoola is associated with Swapa which is a Kaphaja Bhava (numbness), If the Shoola is associated with Daha, which is a Pittaja Bhava and Vida- Vata Stambha (Obstruction to stool and flatus) then Vata Dosha should be considered as prime. The fourth factor is timing, if the pain aggravates in the morning, then the condition is Kaphanubandha Vataja Shoola. If it aggravates in the afternoon, Pittanubandha is there and if it aggravates at night, it will be mostly Kevala Vatika in nature. Also the pattern of Shoola, i.e. if the pain is intermittent or fluctuating then it's Kevala Vatika because Vata Dosha is having Vishama Vega. If the pain is the acute onset and with severe intensity then it is having Pittanubandha and if the pain is dull, it is showing Manda vega and is having Kaphanubandha.

The sixth factor is exacerbating and relieving factors. i.e the concept of Upashaya and Anupashaya in Ayurveda. like in the case of Vataj Shoola it gets aggravated During cold weather, in the evening, during or after digestion of food, cloudy and cold weather, whereas get relived by hot fomentation, oil massage, fatty and warm foods and drinks. Annadrava Shoola having the characteristic features of pain before and during digestion of food and gets relieved after vomiting. While in Parinama Shoola abdominal pain precipitates and aggravates during digestion of food and get relived after digestion of food or by Vaman after food. The seventh factor is the severity and in case of 
severe pain, Vata-Pittaj or Sannipataj Shoola is considered. Thus, depending upon the diagnosis, the management of Shoola can be aimed at removing causative factors and normalising the Prakupita Vata to relieve the pain.

\section{CONCLUSION}

Shoola is the commonest symptom mentioned in Ayurvedic text produced due to the prominence of Vata either due to obstruction or due to Swatantra Vata Prakopa. Shoola explained by Madhavkar after the Amavata specifically indicates the Udarshoola. It includes all the pathological conditions caused due to visceral, somatic or referred pain. Some characteristics attributed to pain are site, character, associated symptoms, timing (duration, course and pattern) exacerbating and relieving factors, severity, onset and comprehensive patient history for an accurate diagnosis. Normalising the Prakupita Vata is the hallmark feature of pain management in Ayurveda. As pain is both a physical and psychological effect, normalizing the Shareerika and Manasika Dosha helps in attaining a pain-free state. It is to be noted that this Shoola could not get full disease status even in today's modern medicine, as the Shoola is considered a major symptom of various diseases occurring in the gastrointestinal tract.

\section{REFERENCES}

1. Sharma P.V., Charak Samhita (Text with English translation), Sutrasthana 30, Arthedashmahamuliya adhyaya, Verse 26, VI ${ }^{\text {th }}$ Edition, Chaukhamba orientalia, Varanasi, 2000, Page No. 240.

2. Sharma P.V., Charak Samhita (Text with English translation), Sutrasthana1, Deerghajivitiya adhyaya, Verse 24, VI ${ }^{\text {th }}$ Edition, Chaukhamba orientalia, Varanasi, 2000, Page No.4.

3. Sharma P.V., Charak Samhita (Text with English translation), Sutrasthana 20, Maharogadhyaya, Verse 20, VI ${ }^{\text {th }}$ Edition, Chaukhamba orientalia, Varanasi, 2000, Page No.143.

4. Tripathi Brahmanand, Ashtang Hridayama of Srimad Vagbhata with Nirmala Hindi commentary, Nidansthan 1, Sarvaroganidan adhyaya, Verse 2, Chaukhamba Sanskrit pratishthan, Delhi, Reprinted 2012, Page 430
5. Sharma P.V., Charak Samhita (Text with English translation), Sutrasthana 4, Shadvirechanshatashriya adhyaya, Verse 17-18, VI $^{\text {th }}$ Edition, Chaukhamba orientalia, Varanasi, 2000, Page No. 29.

6. Jadavji Trikamji Acharya, Susruta Samhita of Sushruta with the Nibandhasangraha panjika of Sri Gayadasaacharya on Nidansthana, Uttartantra adhyaya 42, Gulma pratishedh vyakhya, Verse 76, Krushnadas academy publication, Varanasi, Reprint 1998, Page no. 723.

7. Prof. K.R. Srikanta Murthy, Madhava nidanam( Roga Vinischaya) of Madhavkara Treatise on Ayurveda, translated into English. Adhyaya 26, Shoolaparinamshoola-annadravashoola Nidan, Chaukhamba orientalia, Varanasi, VI ${ }^{\text {th }}$ edition, 2004, Page No.97-100.

8. Jadavji Trikamji Acharya, Susruta Samhita of Sushruta with the Nibandhasangraha panjika of Sri Gayadasaacharya on Nidansthana, Uttartantra adhyaya 42, Gulma pratishedh vyakhya, Verse 76, Krushnadas academy publication, Varanasi, Reprint 1998, Page no. 723.

9. Veni Madhav Shastri Joshi and Narayan hari Joshi, Ayurvediya Shabdakosha, Maharashtra sahitya aani Sanskriti mandal, Mumbai, Page No 1479.

10. Rajaradhakantadev bahadur, Shabdakalpadrum, Pancham bhag, Naga publishers, Delhi, ReprintedVikram savant-2060, page No. 130.

11. Monier Williams, A Dictionary English and Sanskrit, Motilal Banarasidas publishers, Delhi page No. 566, ISBN 81-208-0454-6

12. Vd. Laksmipati Sastri, Yogaratnakar, Vidyotini Hindi commentary, Edited by Bhishagratna Brahmasankar Sastri, Uttarardha Adhyaya 1, Shool nidan, Verse 1-2, Chaukhamba Prakashan, Reprint Edition 2012, Page No. 1,2.

13. Sharama P.V., Charak Samhita (Text with English translation), Vimansthana 2, Trividhakukshiya viman, Verse 7, VI $^{\text {th }}$ Edition, Chaukhamba orientalia, Varanasi, 2000, Page No. 310.

14. Sharma P.V., Charak Samhita (Text with English translation), Nidan sthana 3, Gulma nidan adhyaya, Verse7, VI ${ }^{\text {th }}$ Edition, Chaukhamba orientalia, Varanasi, 2000, Page No. 264-265.

15. Sharma P.V., Charak Samhita (Text with English translation), Chikitsasthana 15, Grahanidosha chikitsa adhyaya, Verse 61,62, VI ${ }^{\text {th }}$ Edition, Chaukhamba orientalia, Varanasi, 2000, Page No. 254. 
16. Sharma P.V., Charak Samhita (Text with English translation), Chikitsasthana 28, Vatavyadhichikitisam adhyaya, Verse 24-26, VI ${ }^{\text {th }}$ Edition, Chaukhamba orientalia, Varanasi, 2000, Page No. 463.

17. Sharma P.V., Charak Samhita (Text with English translation), Chikitsasthana 28, Vatavyadhichikitisam adhyaya, Verse 61- 62, VI ${ }^{\text {th }}$ Edition, Chaukhamba orientalia, Varanasi, 2000, Page No. 467.

18. Sharma P.V., Charak Samhita (Text with English translation), Chikitsasthana 28, Vatavyadhichikitisam adhyaya, Verse 15-19, VI ${ }^{\text {th }}$ Edition, Chaukhamba orientalia, Varanasi, 2000, Page No. 462-463.

19. Jadavji Trikamji Acharya, Susruta Samhita of Sushruta with the Nibandhasangraha panjika of Sri Gayadasaacharya on Nidansthana, Uttartantra adhyaya 42 , Gulma pratishedh vyakhya, Verse 82-87, 117-119, 131-139, 142-144, Krushnadas academy publication, Varanasi, Reprint 1998, Page no. 723726.

20. Prof. K.R. Srikanta Murthy, Madhava nidanam( Roga Vinischaya) of Madhavkara Treatise on Ayurveda, translated into English. Adhyaya 26, Shoolaparinamshoola-annadravashoola Nidan,Verse 15-20, Chaukhamba orientalia, Varanasi, $\mathrm{VI}^{\text {th }}$ edition, 2004, Page No.99-100

21. Prof. K.R. Srikanta Murthy, Madhava nidanam( Roga Vinischaya) of Madhavkara Treatise on Ayurveda, translated into English. Adhyaya 26, Shoolaparinamshoola-annadravashoola nidan, Verse 21,22 Chaukhamba orientalia, Varanasi, VIth edition, 2004, Page No. 100.

\section{Source of Support: Nil \\ Conflict of Interest: None Declared}

How to cite this URL: Kulkarni Archana A. \& Joshi Seema D: Review Of Shoola With Special Reference To Madhav Nidan. International Ayurvedic Medical Journal \{online\} 2021 \{cited July, 2021\} Available from: http://www.iamj.in/posts/images/upload/2985 2992.pdf 